\title{
PENERAPAN ELEMEN VERNAKULAR PADA PERANCANGAN TAMAN KRIDA BUDAYA JAWA TIMUR SEBAGAI PROSES POPULAR VERNACULAR
}

\author{
Junianto* \\ Program Studi Arsitektur, Fakultas Teknik Universitas Merdeka Malang, \\ *junianto@unmer.ac.id
}

\begin{abstract}
ABSTRAK
Hasil rancangan arsitektur dalam fungsi baru seringkali dijumpai pemakaian sumber ide-ide desainnya dari arsitektur tradisional. Karya arsitektur baru yang merupakan wujud perulangan atau mencontoh tersebut merupakan gejala Popular-Vernacular. Kajian suatu hasil rancangan Arsitektur atau bangunan, melalui elemen vernakular semacam ini, merupakan salah satu cara mengukur evolusi nilai-nilai tradisional masyarakat. Pengkajian elemen vernakular pada kasus Taman Krida Budaya Jawa Timur dilakukan melalui studi komparasi dengan grand design-nya. Terdapat temuan di Taman Budaya Jawa Timur Malang yang menunjukkan sejumlah ciri elemen-elemen arsitektur tradisional. Elemen-elemen tersebut diperlihatkan pada bentuk atap, soko guru, ornamen, dan tata ruangnya. Taman Krida Budaya Jatim dibangun dengan dominasi pendopo joglo. Utamanya, kompleks bangunan ini berfungsi sebagai konservasi dan eksposisi budaya Jawa Timur. Bentuk budaya yang diwadahi antara lain kesenian, benda kuno bersejarah, benda seni, serta arsip-arsip karya sastra.
\end{abstract}

Kata kunci-arsitektur, populer, vernakular.

\begin{abstract}
Keywords - architecture, popular, vernacular.

\section{PENDAHULUAN}

Arsitektur vernakular sering disebut juga sebagai 'architecture without architects' dan terjadi di masyarakat.

Dalam perkembangan tradisi ber-arsitektur, para arsitek seringkali merancang dengan mengadopsi
\end{abstract}

The architectural design results in the new function are often found using sources of design ideas derived from traditional architecture. The new architectural work which is a form of repetition or imitation is a symptom of Popular-Vernacular. The study of an architectural or building design result, through vernacular elements of this kind, is one way to measure the evolution of traditional values of society. Assessment of vernacular elements in the Taman Krida Budaya East Java case was carried out through comparative studies with its grand design. It was found that the traditional architectural element characteristics were shown on the roof shape, "soko guru", and room layout. Taman Krida Budaya East Java was built with the joglo pavilion domination which serves as a form of conservation and cultural exposition of East Java. The accommodated cultural forms include arts, historical ancient objects, art objects, and literary archives.

elemen-elemen arsitektur vernakular. Produk karya desain ini disebut "popular vernakular".

Taman Krida Budaya Jawa Timur adalah salah satu produk popular vernakular. Dalam telaah perihal arsitektur vernakular semacam ini, esensi ke- 
vernakular-an terletak pada 'alasan' atau latar belakang pemakaian atau perulangan elemen-elemen vernakular.

Pada bagian depan Taman Krida Budaya Jatim, secara dominan berdiri pendopo Joglo yang difungsikan untuk pentas-pentas budaya dan pameran. Bagian tengah dari kompleks ini, berupa open teater, sering digunakan untuk pentas kesenian-kesenian Jatim yang sesuai, seperti reog, kuda kepang, dsb. Pada bagian belakang, di sekitar teater terbuka, dibangun 7 replika rumah tradisional, sebagai lambang dari 7 zona etnis di Jatim. Bangunan tersebut berfungsi sebagai ruang pamer benda-benda seni budaya dari ketujuh etnis tersebut.

Tradisi joglo dalam kompleks Taman Budaya Jatim dibangun dengan ungkapan simbolik. Joglo tersebut tanpa empyak emper memakai tumpang sari 5 tingkat, memakai uleng ganda dan godhegan. Bentuk semacam ini mengingatkan joglo pada Kraton Yogyakarta dan Surakarta. Ungkapan lain dalam kompleks ini adalah elemen-elemen detail (dekoratif) yang mengakomodasi citra daerah sebagai akar budaya Jatim.

Rancangan bangunan baru dengan mengadopsi elemen-elemen vernakular, merupakan indikator, seberapa besar akar tradisi masih dilestarikan oleh masyarakat pemilik tradisi tersebut. Dalam penelitian ini, dimungkinkan juga ditemukan alasan pelestarian tradisi berarsitektur budaya masa lalu. Tidak sekedar menyangkut fisik elemen arsitektural saja, melainkan juga menyangkut kultural masyarakat. Termasuk juga, terkait dengan perkembangan potensi daerah seperti potensi-potensi penyediaan bahan bangunan, tukang- tukang bangunan, dan juga seniman ukir atau pengrajin setempat.

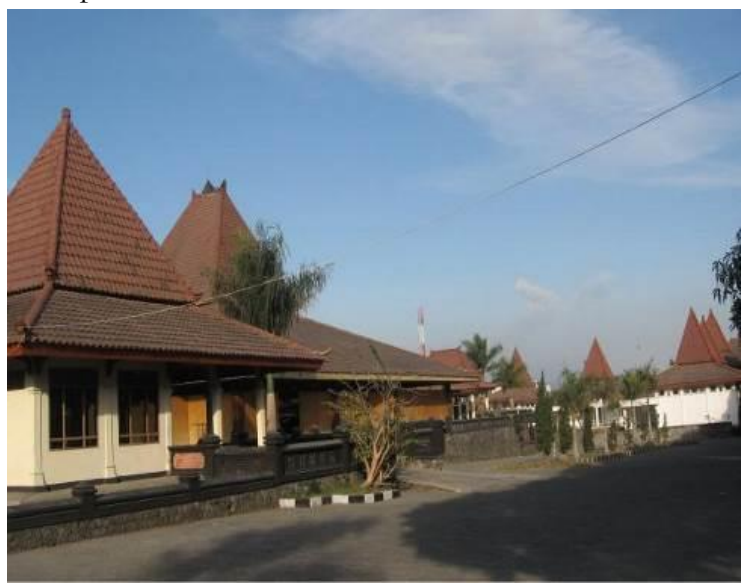

Gambar 1. Komplek Taman Krida Budaya Jatim sebagai Representasi Wadah atau 'Rumah' Budaya Jawa Timur (Sumber : dokumentasi peneliti, 2017)

\section{Gejala Arsitektur Vernakular}

Wujud Vernakular pada dasarnya dapat dilihat dari suatu gejala (kejadian) pengulangan atau peniruan, yang terdapat dalam fenomena arsitektur. Dengan demikian, vernakular sebenarnya telah terjadi sejak Rancanomintbangunan baru dengar seiring dengan dikenalnya arsitektur oleh manusia. Dan tentu saja gejaIa vernakular tersebut terus akan berlangsung hingga kini dan masa akan datang.

Sesuai dengan sifatnya sebagai bentuk "peniruan" yang disengaja, arsitektur vernakular selalu memiliki "alasan" perancangan (penerapan). Berkait dengan hal tersebut pula, dapat dikatakan bahwa arsitektur vernakular sebenarnya bersifat "liar". Artinya, dia bisa terjadi 
dimana saja dan dengan alasan yang beraneka. Bentuk perujudannyapun dapat berubah-ubah, berbeda dengan yang "asli" (grand design) nya. Sebagai contoh adalah Papan nama Rumah makan Minang Jaya yang beratap Bonjong, berada di Pasuruan. Atap bonjong adalah milik rumah tradisional di wilayah budaya Minangkabau. Perujudan dalam konteks tradisi tersebut, penuh makna. Apabila kemudian hadir dalam bentuk dan fungsi lain, dan bahkan di 'wilayah budaya' lain, kenyataan ini manjadi salah satu sifat vernakular yang "liar" tersebut.

Gejala vernakular dalam arsitektur dikenal dua macam, yakni Traditional Vernacular dan Popular Vernacular. Pengulangan atau peniruan bentuk dan fungsi yang terjadi dalam satu wilayah budaya, lebih tepat disebut Traditional Vernacular. Apabila hanya memenuhi salah satu ciri, lebih tepat dinamai Popular Vernacular. Perancangan arsitektur dalam era modern ini, lebih banyak ditemui bentuk popular vernakular.

Ciri lain dari arsitektur vernakular adalah mencontoh grand design yang terkait dengan nilai-nilai sosial-kultural, dengan kata lain diyakini oleh sekelompok masyarakat. Mencontoh karya design seorang arsitek unggul, bukan merupakan vernakular. Pada kasus ini, karya arsitek sebagai yang "asli" (grand design), tidak merupakan ungkapan nilai-nilai sosial-kultural tertentu.

Fenomena arsitektur vernakular sebenarnya ekuivalen (sama) dengan fenomena sosial. Dengan demikian, dalam memahami arsitektur vernakular diperlukan ketajaman membaca gejala sosial, sebagai bekalnya. Hal demikian terkait dengan upaya membaca alasan (gejala sosial) yang terjadi dalam "peniruan". Sebagai contoh, dalam era tahun 1980-an, muncul banyak rumah model Spanyolan dan gedung-gedung ber-Atrium. Beberapa tahun terakhir ini marak rumah-rumah, ruko dan juga apartemen, bergaya Mediteranian. Semua contoh tersebut adalah bentuk perujudan Popular vernakular.

Beberapa tahun setelah para arsitek Indonesia mencetuskan komitmen bersama (Yogyakarta, 1982) untuk mencari bentuk arsitektur Indonesia, terjadi polemik gaya Spanyolan. Dalam polemik tersebut, terjadi pengingkaran terhadap arsitektur Spanyolan. Mereka menganggap gaya Spanyolan bukan arsitektur Indonesia, dan hanya sebagai "tamu" di negeri ini. Kelompok yang lebih arif menganggap Spanyolan adalah salah satu bentuk arsitektur Indonesia dalam konteks sebuah era/jaman. Dalam kenyataan memang tidak bisa dipungkiri bahwa gaya Spanyolan adalah gejala sosial yang terjadi di negeri ini. Memahami arsitektur vernakular, adalah upaya menjawab "alasan" disebalik gejala sosial seperti contoh tersebut. Mempertentangkan sebuah fakta, atau bahkan mengingkarinya adalah suatu kesia-siaan.

Dalam studi tentang vernakular, terdapat tujuh domain yang bisa digunakan sebagai titik tolak pembahasan, yaitu :

a. Estetika kualitas lingkungan.

b. Tipologi

c. Evolusi : kontinuitas dan perubahan.

d. Difusi : antar kelompok, antar daerah. 
e. Fisik : teknologi, material, site, iklim, dll

f. Sosial : struktur sosial, kelompok serta kelembagaan.

g. Budaya : revival vernacular.

Dalam kajian tersebut, dipilih domain kajian dari sudut pandang gabungan, yakni dari segi budaya dan evolusi.

\section{Bangunan Tradisional Jawa}

Bangunan Joglo merupakan salah satu bentukan arsitektur tradisional Jawa, dalam fungsi rumah tinggal. Nilai-nilai joglo sebagai bangunan tradisional, tidak saja dalam bentuk atapnya, tetapi juga tata ruang di dalam dan di luar bangunan. Membandingkan bangunan Joglo dalam konteks tradisional dengan hasil-hasil sekarang, dimungkinkan terjadi banyak pergeseran (perubahan).

Joglo sebagai tradisi budaya Jawa, tidak berbeda dengan produk budaya lainnya, yakni bersumber dari Kraton. Ada keyakinan bahwa masyarakat Jawa merasa hidup di ruang hampa, apabila tidak mengikatkan diri dengan pusat kerajaan (Darsiti, 1989). Dalam hal ini Kraton bermakna sebagai pusat orientasi spiritual. Bentuk mengikatkan diri tersebut, diwujudkan dengan meniru tradisi yang diberlakukan di dalam lingkungan Kraton. Beberapa contoh tradisi yang terdapat dalam kehidupan Kraton antara lain, memperingati kelahiran bayi, perkawinan, kematian, cara berpakaian, berkesenian, dan juga tradisi membangun rumah.

Kraton adalah tempat tinggal raja, Kraton berbentuk Joglo, dimaksudkan sebagai simbol meru (gunung), yang diyakini merupakan tempat tinggal para dewa.
Simbolisasi demikian, berasal dari keyakinan Budha Mahayana dalam konsepsi Jambudwipa. Raja dalam keyakinan tersebut, dan selanjutnya dalam keyakinan tradisi Jawa, dianggap sebagai keturunan dewa. Termasuk juga, dalam hal ini putra-putri raja, berhak mewarisi tradisi berarsitektur joglo.

Perkembangan joglo di luar lingkungan kehidupan kraton, bermula dari tempat tinggal Bupati (kabupaten). Bupati pada masa kerajaan ini berperan sebagai wakil raja yang berada di luar wilayah Negeri agung. Bermula dari peniruan semacam ini, selanjutnya berkembang penerapan Joglo pada rumah-rumah masyarakat umum, yang berstatus sebagai pirnpinan daerah yang berlingkup sempit. Perkembangan berikutnya, joglo dibangun oleh orang-orang golongan mampu. Hingga saat sekarang, joglo berkembang dalam bentuk, fungsi, dan alasan yang sangat kompleks.

Masih banyak ditemui pembangunan baru pendopo kabupaten (Dati II masa sekarang, berbentuk joglo. Tidak saja ditemui pada pendopo kabupaten, ternyata di tingkat kecamatan dan kelurahan, juga ditemui bentuk pendopo joglo. Beberapa contoh dapat diantaranya pendopo kabupaten Malang, kab. Pasuruan, kab. Probolinggo, kab. Blitar, dan sebagainya.

Pemilihan bentuk joglo untuk pendopo tersebut, didasari oleh banyak alasan. Dari segi fungsi, pendopo untuk kabupaten atau kecamatan atau kelurahan masih digunakan untuk pertemuan, musyawarah, dan juga 
menerima tamu penting. Fungsi demikian masih manunjukkan tali benang merah dengan asal mula fungsi pendopo joglo rumah-rumah pangeran atau pejabat Kraton.

\section{Transformasi Arsitektur Vernakular}

Tradisi vernakular, adalah cara hidup yang berdasarkan pada tradisi dan kegiatan yang berlangsung turun temurun, yang jauh dari pilitik dan undang-undang (Rapoport, 1983). Budaya vernakular, juga memperlihatkan bahwa identitas manusia dibentuk oleh keikutsertaannya dalam kelompok atau keluarga besar. Dalam pengertian tradisi vernakular, semua orang dalam masyarakat tersebut mengetahui tipe bangunan dan bagaimana membuat bangunan.

Menurut Rapoport (1983), istilah bangunan vernakular adalah suatu bangunan, yang terbentuk karena latar belakang sosial budaya masyarakat. Dengan pemahaman ini, dapat diartikan bahwa bangunan vernakular merupakan ungkapan budaya dan jalan hidup masyarakat. Pemahaman tersebut, juga sesuai dengan pengertian bahwa vernakular sebagai cerminan langsung dari masyarakat dalam mencoba mengekspresikan sesuatu.

Dalam kategori folk architecture, terdapat perbedaan antara arsitektur primitif dan arsitektur vernakular. Arsitektur vernakular dibedakan menjadi vernakular tradisional dan vernakular populer (Rapoport, 1969). Vernakular tradisional merupakan arsitektur yang berlandaskan pada tradisi. Vernakular populer merupakan arsitektur yang bertolak dari institusi.
Arsitektur vernakular dapat dikaji dari aspek karakteristik proses maupun produknya. Proses yang dimaksud adalah bagaimana bangunan atau lingkungan tersebut dibentuk dan dirancang dengan mengidentifikasi 'aktor'nya. Sedangkan yang dimaksud produk berarti 'benda' yang dihasilkan oleh masyarakat, dengan melihat morfologinya, kompleksitasnya, dan bagaimana faktor lingkungan dalam memberikan gambaran bangunan tersebut.

Menurut Rapoport (1983) kebudayaan berubah bersamaan dengan berubahnya lingkungan akibat pembangunan. Karena terjadi dalam waktu yang bersamaan, akan dapat diidentifikasi elemen-elemen mana yang cepat berubah, dan mana yang perlahan dan bahkan tidak berubah. Elemen-elemen yang tidak berubah dan dipertahankan, merupakan komponen penting dalam lingkungan tradisional. Sedangkan elemen lainnya yang mengalami perubahan, merupakan elemen tepi. Perubahan-perubahan yang terjadi pada elemen ini, tidak begitu prnting. Seringkalim tidak hanya terjadi perubahan secara cepat, tetapi juga bersifat total dan menyerap hal-hal baru secara cepat.

\section{Penerapan Elemen Vernakular pada Perancangan Taman Krida Budaya Jawa Timur}

Penelusuran elemen vernakular pada Taman Krida Budaya Jatim ini, menggunakan metoda Deskripsi, Kategorisasi, Klasifikasi, dan Eksplanasi. Penelitian dilaksanakan dengan cara menginventarisir elemenelemen arsitektur yang bersumber dari arsitektur vernakular. Kemudian, elemen-elemen tersebut 
dipisah-pisah, dikategorikan berdasarkan wujud, gaya/ style dan bentuknya.

Beberapa variabel yang digunakan untuk mengkaji lingkungan dan bangunan vernakular (Hubka, dalam Moore, 1980), meliputi :

1. Tradisi sebagai cara.

Semua vernakular dan arsitektur vernakular, berkarakter sebagai pemelihara tradisi. Hal demikian, bukan berarti bahwa arsitektur vernakular tidak mengalami perubahan. Perubahan yang terjadi merupakan penerusan atau perbaikan dengan tidak menghambat keberadaan sistem nilai yang ada.

2. Mengakomodasi perubahan.

Sistem arsitektur vernakular tidak statis, karena mengakomodasi perubahan, tetapi berstrategi khusus dalam pengaturan dan pengawasan perubahan yang membatasi eksperimen. Perubahan terjadi hanya terbatas pada areal minor, sedangkan bagian-bagian yang fundamental tetap dipertahankan.

3. Individual dalam masyarakat.

Arsitektur vernakular menyampaikan image tentang manusia pemakainya. Individualisme dibatasi dan disalurkan dalam area-area yang spesifik, serta mendesak individualisme mendukung keseragaman kolektif.

4. Vernakular dan simbolisme.

Tampilan fisik dan simbolisme yang terkandung dalam bangunan vernakular, mendukung pemeliharaan tradisi, dan memberikan nilai simbolis tentang kehidupan sehari-hari.
5. Desainer dan Klien.

Hubungan antara klien dan desainer vernakular, sangat sederhana. Keduanya mempunyai peran yang sama. Hubungan tersebut, diwujudkan melalui dialog atau diskusi. Terjadi interaksi diantara mereka dalam memasukkan sistem nilai yang sama, untuk mendapatkan kesesuaian yang sempurna.

Selanjutnya, untuk mengetahui adanya pengaruh elemen-elemen arsitektural tadisional Jawa Timur, dilakukan perbandingan terhadap fasade, bentuk, tata ruang, dan dekorasi pada obyek penelitian dengan elemen atau unsur arsitektur tradisional Jawa Timur. Dugaan keterkaitan dan relevansi penggunaan elemen tradisional tersebut, diartikan sebagai ungkapan tradisi yang signifikan.

\section{METODE PENELITIAN}

\section{Proses Analisis Elemen Vernakular}

Hasil pengumpulan data yang dilakukan melalui pengamatan, pengukuran, observasi, wawancara, serta studi literatur terhadap obyek studi tersebut, selanjutnya dilakukan klasifikasi, deskripsi dan eksplanasi.

Analisis dilakukan dengan metode eksplanasi, yakni penjelasan elemen vernakular yang ditransformasikan dalam Taman Budaya Jatim, berdasarkan teori-teori serta fenomena yang terjadi di lapangan. Hasil dari studi tersebut, kemudian dikembangkan dengan penelusuran makna tradisional pada setiap elemen vernakular. Dengan demikian, bisa didapatkan temuan elemen vernakular apa saja yang diimplementasikan sebagai landasan perancangan Taman Krida Budaya 
Jatim. Temuan elemen vernakular tersebut, kemudian dijabarkan latar belakang alasannya.

\section{PEMBAHASAN}

Penelitian ini merupakan upaya memahami sejarah arsitektur Nusantara, khususnya yang berlatar budaya Jawa Timur. Taman Budaya Jatim dipilih sebagai studi kasus, karena hingga kini masih banyak ditemui bangunan-bangunan "modern" dalam bentuk tampilan arsitektur tradisional. Selain itu, pemahaman arsitektur Nusantara terasa sangat abstrak, sehingga perlu mengambil salah satu kasus Taman Budaya Jatim, yang memiliki area budaya. Memahami akar tradisi dan keberlangsungan berarsitektur di Nusantara, dalam hal ini Jawa Timur diartikan sebagai sebuah pendekatan eksplanasi hadirnya elemen-elemen vernakular pada bangunan tersebut.

Taman Budaya Jatim sebagai transformasi wujud arsitektur vernakular, mengalami perkembangan dalam hal teknologi (bahan), proses dan fungsi. Perkembangan tersebut seiring dengan perubahan kultural masyarakat. Perkembangan semacam inilah, yang justru mengakibatkan lestarinya produk tradisional, dalam hal ini arsitektur. Keterkaitan elemen-elemen vernakular yang diterapkan di Taman Krida Budaya Jatim, dengan grand design (arsitektur aslinya), merupakan suatu esensi dalam temuan ini.

Hasil dari penelitian ini berupa elemen-elemen vernakular yang masih dilestarikan dalam perwujudan bangunan baru dan memiliki nilai simbolis kedaerahan. Untuk mendapatkan gambaran 'keterkaitan' elemen- elemen vernakular dengan grand design-nya, dilakukan wawancara dengan narasumber. Dalam penelitian ini, ada dua narasumber, yakni Pemilik (pengelola) Taman Krida Budaya Jatim, dan Perencana. Temuan penelitian terhadap elemen-elemen vernakular yang terdapat di dalam rancangan Taman Krida Budaya Jatim, meliputi: bentuk bangunan utama (Joglo), gerbang utama, gapura dalam, patung (arca), lampu gantung, dan beberapa ornamen.

\section{Bentuk Bangunan Utama (Joglo)}

Bentuk bangunan Joglo, merupakan simbolisme, yang bersumber dari konsepsi Jambudwipa dalam keyakinan Budha Mahayana.

\section{KONSEP JAMBUDWIPA :}

Benua di tengah berupa Meru, yang dikelilingi 7 cincin pegunungan.

Benua ini sebagai tempathidup para Dewa yang berperan menjadi penyelaras jagad

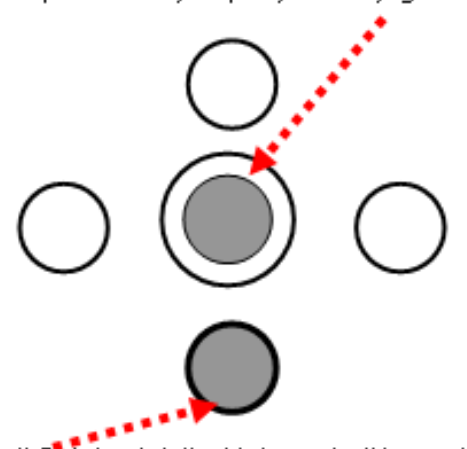

Benua di Selatan ini diyakini menjadi tempat hidup manusia, yang "menyembah" para Dewa.

Gambar 2. Konsep Jambudwipa 
Jagad raya diyakini terdiri dari lima benua, empat buah benua berada di keempat penjuru mata-angin dan sebuah benua berada di pusatnya. Benua pusat ini berupa Meru diyakini sebagai tempat hidup para Dewa. Sedangkan, benua tempat hidup manusia berada di sebelah Selatan.

Konsep Jambudwipa berakar dari keyakinan Budha Mahayana. Konsep simbolis tersebut ditemukan pada kota-kota kerajaan di Asia Tenggara (Geldern, 1982). Keberadaan bentuk Joglo di Kraton Kasunanan Surakarta maupun Yogyakarta, tidak terlepas dari konsepsi Jambudwipa tersebut. Joglo merupakan simbolisasi dari Gunung (meru), yakni sebagai tempat tinggal para dewa. Adapun, raja dianggap sebagai keturunan dewa.

Selain itu, dalam kosmologi Jawa dikenal juga kategori simbolik dua dan tiga. Kategori simbolik dua, menggambarkan keyakinan adanya dua hal berlawanan dalam kehidupan, dan keduanya saling melengkapi. Dua hal yang berlawanan tersebut, antara lain seperti adanya siang-malam, laki-perempuan, tinggi rendah, kaya-miskin, kuat-lemah, baik-buruk, sakral-profan, dan sebagainya.

Kategori simbolik tiga menggambarkan eksistensi raja yang diyakini sebagai "keturunan Dewa" sebagai "penyelaras" dari kedua hal berlawanan tersebut. Kraton sebagai tempat tinggal raja dengan dua buah Alun-Alun sebagai pengapitnya, dalam konsepsi ini, menjadi miniatur "jagad raya”. Masyarakat Jawa tidak bisa hidup terlepas dari abstraksi perihal alam raya atau kosmos tersebut.

Dengan demikian, "Jawa" menjadi semacam "Negara" dalam alam pikir kebudayaan. Proses menjadi bagian dari masyarakat Jawa, merupakan sebuah keniscayaan spiritual dari orang-orang yang meyakininya. Pengikatan diri secara spirit tersebut, terimplementasi dalam perilaku adat kehidupan sehari-hari dengan meniru adat kehidupan Kraton. Sebagai contoh dalam hal upacara kelahiran, perkawinan, dan kematian seseorang.

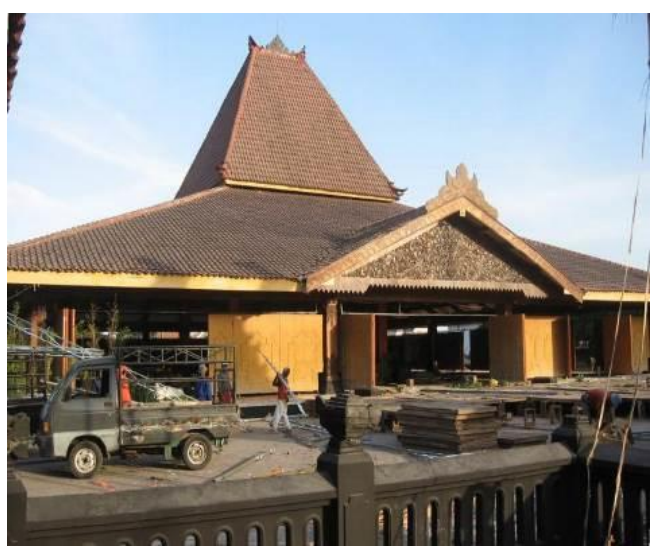

Gambar 3. Joglo Taman Krida Budaya Jatim Menggunakan Atap Susun Dua, dapat Diartikan sebagai 'Wakil' yang Mengepalai Suatu Daerah/ Wilayah. Biasanya Berupa Wilayah Kadipaten.

Bangunan utama pada Taman Krida Budaya Jatim menggunakan bentuk Joglo Lambangsari dengan sistem atap susun, tidak menerus. Sistem rangka utama 
bangunan Joglo tersebut terdiri dari tiga bagian, yaitu : brunjung, soko guru, dan umpak.

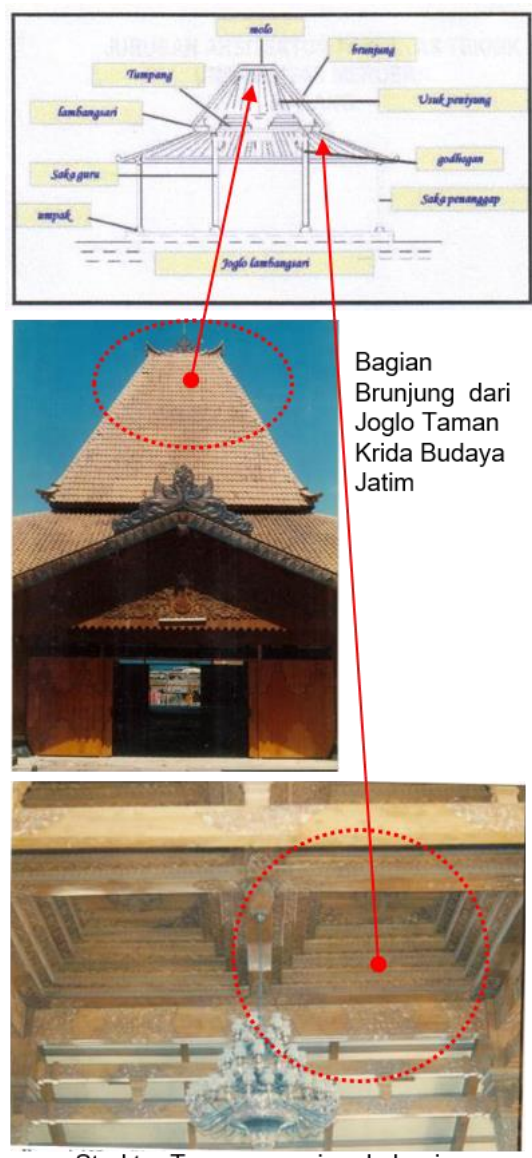

Struktur Tumpang sari pada bagian Brunjung Taman Krida Budaya Jatim.

Gambar 4. Struktur Joglo Tradisional Jawa sebagai Grand Design Taman Krida Budaya Jatim

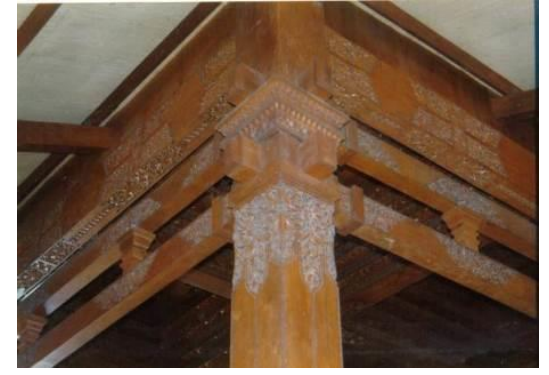

Gambar 5. Pertemuan Sokoguru dengan Struktur Tumpang Sari pada Taman Krida Budaya Jawa Timur

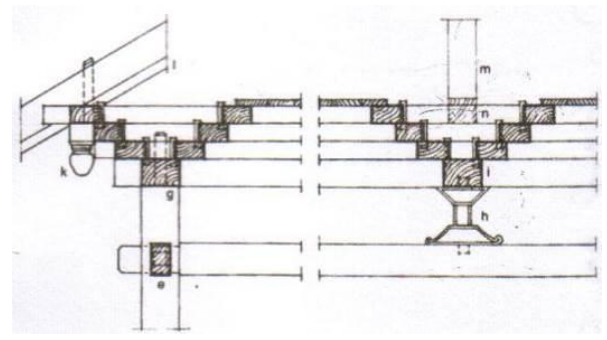

Gambar 6. Struktur Tumpangsari pada Bangunan Tradisional Joglo sebagai Grand Design dalam Perancangan Joglo Taman Krida Budaya Jatim (Bermakna Simbolis sebagai Langit (Alam Arwah))

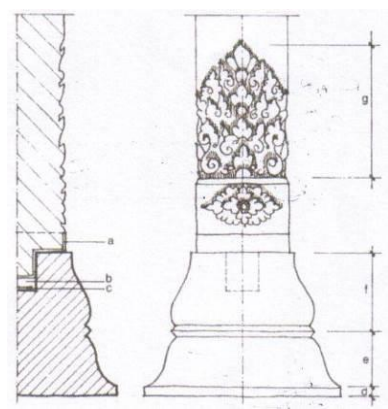

Gambar 7. Umpak melambangkan bahwa manusia hidup berada di permukaan bumi 


\section{Gerbang Utama}

Gerbang Utama pada Kompleks Taman Krida Budaya Jawa Timur dirancang mengadopsi tiga buah candi besar di Jawa Timur, yakni Wringin Lawang di Trowulan, Canda Singosari, dan Candi Penataran di Blitar. Kedua candi tersebut merupakan representasi kerajaan besar pada masa lalu di Jawa Timur.

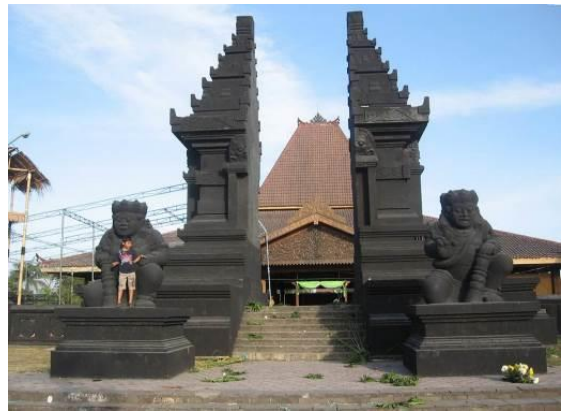

Gambar 8. Gerbang Utama Kompleks Taman Krida Budaya Jatim Mangadopsi Candi Wringin Lawang Majapahit

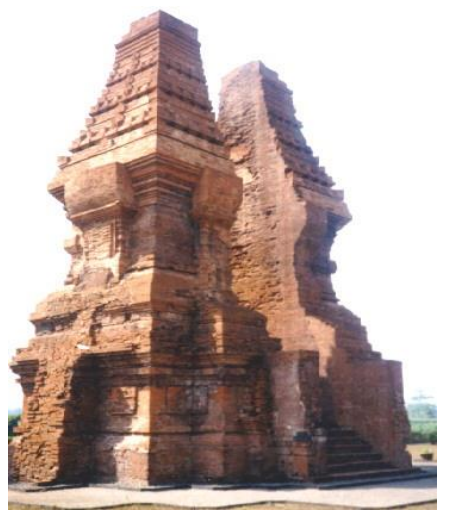

Gambar 9. Candi Wringin Lawang merupakan Gerbang Utama Kerajaan Majapahit di Trowulan, Mojokerto
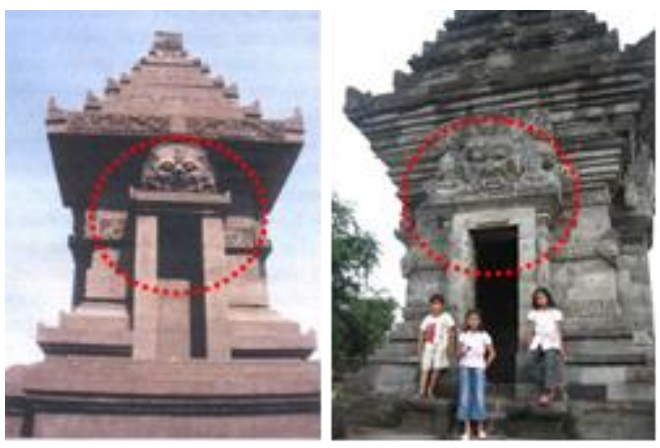

Gambar 10. Gerbang Utama Kompleks Taman Krida Budaya Jatim (dari Arah Samping) Mengadopsi Candi Penataran di Blitar

\section{Gapura Dalam}

Gapura Dalam yang dimaksudkan dalam pembahasan Taman Krida Budaya Jatim adalah gerbang yang menghubungkan antara Pelataran bangunan utama dengan halaman belakang Kompleks ini. Desain gerbang ini mengadopsi Candi Penataran di Blitar dan Goa Selomangleng di Kediri.

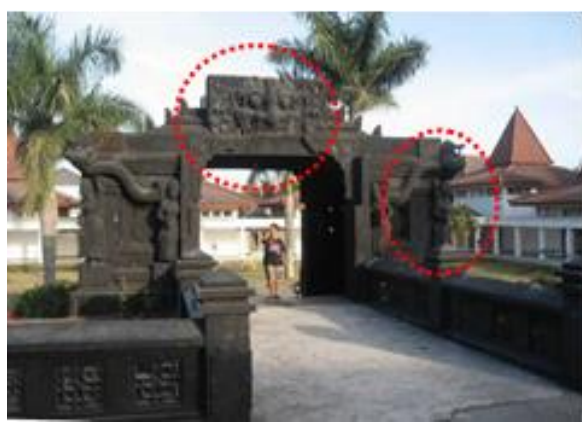

Gambar 11. Gerbang Dalam dari Kompleks Taman Krida Budaya Jatim Mengadopsi Bangunan Candi Penataran dan Goa Selomanglang di Kediri 


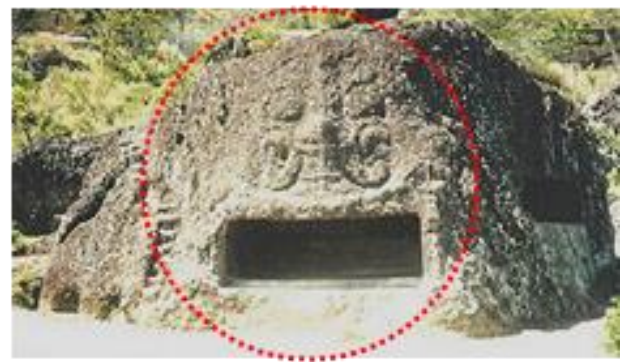

Gambar 12. Goa Selomangleng, Salah Satu Bangunan Kuno Bersejarah di Kediri sebagai Grand Design

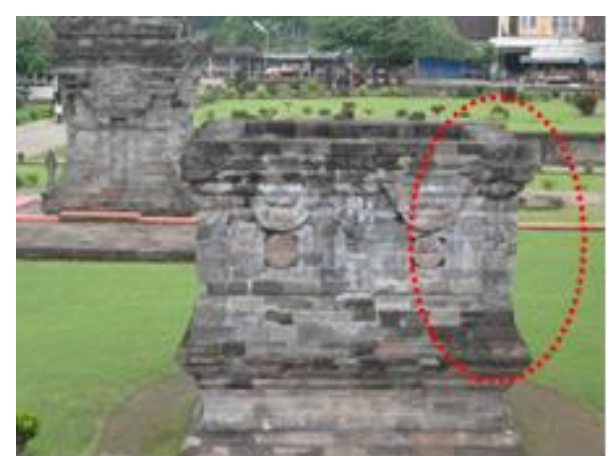

Gambar 13. Salah Satu Bangunan di Candi Penataran, Blitar, sebagai Grand Design

\section{Open Theatre}

Open theatre berada di halaman belakang dari Kompleks Taman Krida Budaya Jatim ini, berfungsi untuk pentas seni tradisional Jawa Timur. Elemen-elemen vernakular tidak selalu berupa elemen fisik semata, akan tetapi juga non fisik berupa aktifitas. Dalam hal ini, berupa pentas kesenian tadisional se-Jawa Timur sebagai wilayah budayanya.
Adapun, rancangan bangunan Open Theatre di Taman Krida Budaya Jatim ini mengadopsi salah satu bangunan di kompleks Keraton Majapahit, yakni Candi Tikus. Candi Tikus merupakan tempat permandian raja.
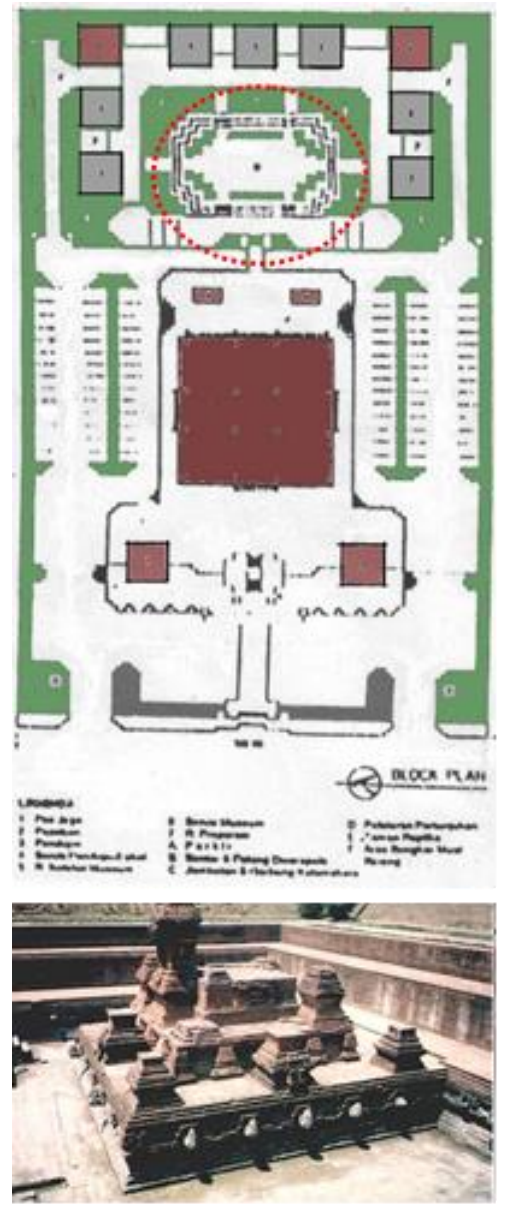

Gambar 14. Candi Tikus di Kompleks Kraton Majapahit sebagai Grand Design Rancangan Open Theatre 


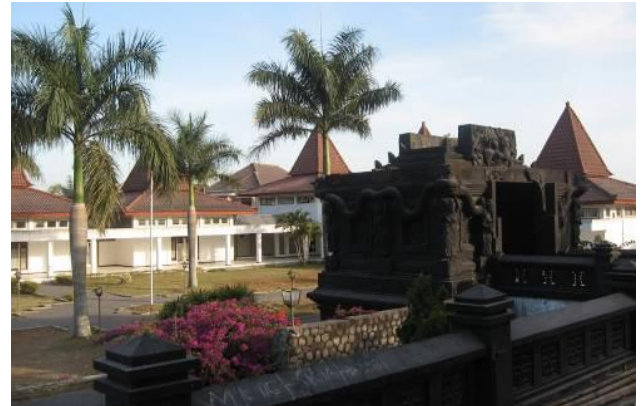

Gambar 15. Open Theatre untuk Pentas Seni Tradisional Jawa Timur di Halaman Bagian Belakang Kompleks Taman Krida Budaya Jatim. Bentuknya Mengadopsi Candi Tikus, Trowulan

\section{Gerbang Samping}

Gerbang samping di bagian dalam Taman Krida Budaya Jatim terdiri dari dua gerbang, kiri dan kanan. Gerbang ini menuju ke halaman belakang Kompleks. Desain gerbang tersebut mengadopsi bentuk Candi Badut yang berada di kota Malang.

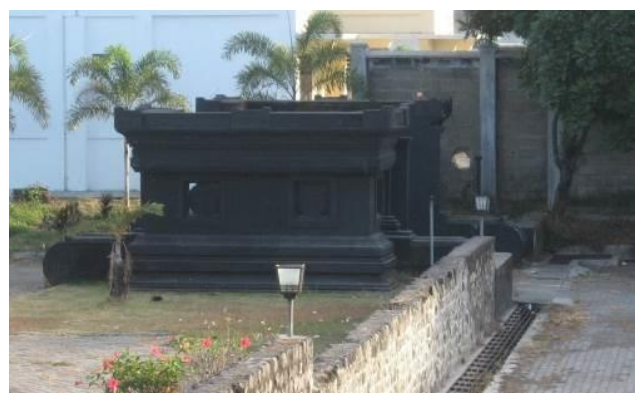

Gambar 16. Gerbang Samping Taman Krida Budaya Jatim menjadi Perantara Halaman Tengah menuju Halaman Belakang. Bentuk Bangunan Mengadopsi Candi Badut di Malang

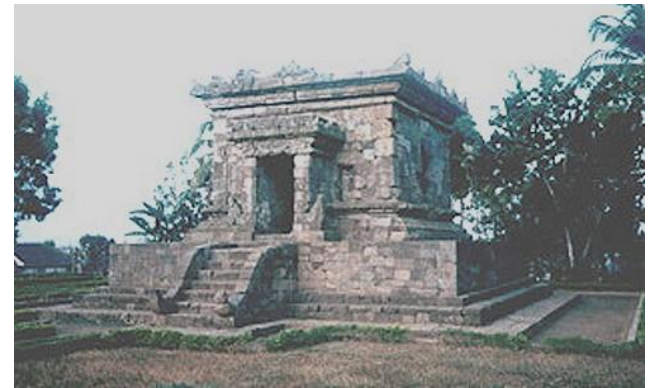

Gambar 17. Candi Badut sebagai Grand Design

\section{Patung Dwaparla}

Patung Dwaparla berada di depan Gerbang utama dari kompleks Taman Krida Budaya Jatim, berjumlah dua buah berada di samping kiri-kanan gerbang. Patung ini merupakan peninggalan pada masa Kerajaan Singosari. Patung Dwaparla merupakan lambang penjaga Gerbang kerajaan.

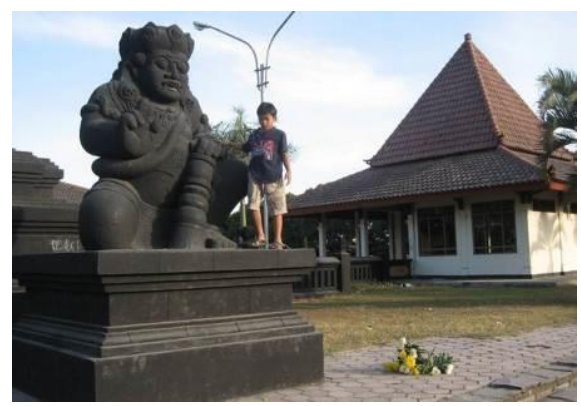

Gambar 18. Sepasang Patung Dwaparla di Depan Gerbang Utama, Taman Krida Budaya Jatim, Mengadopsi Patung di Candi Singosari 


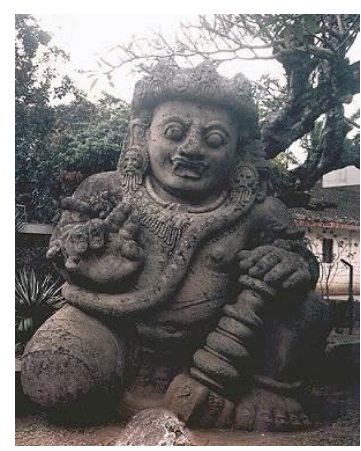

Gambar 19. Dwarapala di Komplek Candi Singosari

\section{Lampu Gantung}

Lampu gantung yang berada di bangunan utama merupakan ragam hias khas Pasuruan. Lampu ini menjadi elemen estetis yang sekaligus menjadi vocal point di dalam gedung utama tersebut. Lampu hias ini terdiri dari tiga tingkat, yaitu:

1. bagian atas, terdiri dari 6 anak lampu, melambangkan Rukun Iman dalam ajaran Islam;

2. bagian tengah, terdiri dari 12 anak lampu;

3. bagian dasar, terdiri dari 24 anak lampu.

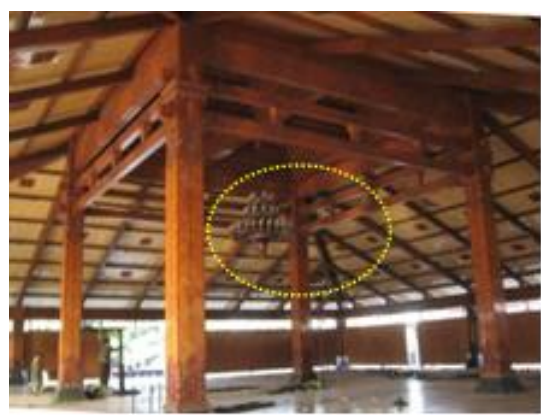

Gambar 20. Lampu hias di Pendopo Joglo, Taman Krida Budaya Jatim, dari Pasuruan

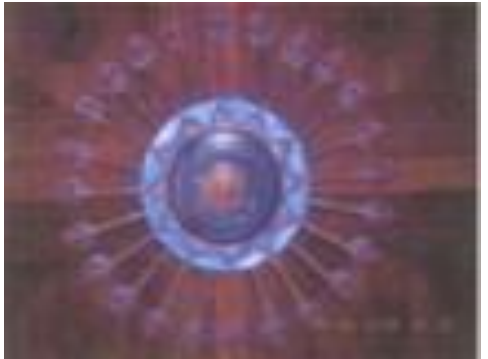

Gambar 21. Lampu Hias Terlihat dari Bawah seperti Lambang Surya Majapahit

\section{Ornamen}

Dekorasi yang berupa ornamen di Taman Krida Budaya Jatim, antara lain berupa balustrade pagar. Ornamen dekoratif ini bermotif flora dan fauna. Ornamen tersebut mengadopsi ornamen yang berada di Candi Penataran, Blitar.

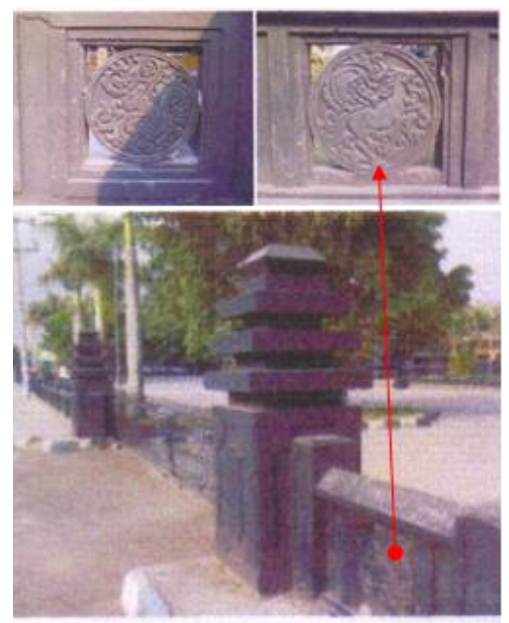

Gambar 22. Ornamen Dekoratif di Taman Krida Budaya Jatim, Berupa Tupai, Burung, dan Kuda Mengadopsi

Ornamen Candi Penataran, Blitar 


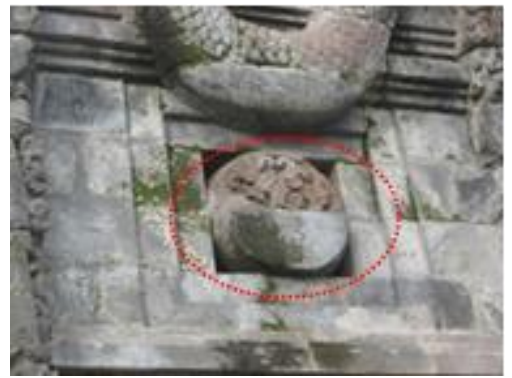

Gambar 23. Ornamen Dekoratif di Candi Penataran, Blitar. sebagai Grand Design

\section{Layout Plan}

Layout plan pada kompleks Taman Krida Budaya Jatim berpola meniru tata ruang rumah tradisional Jawa. Adapun fungsi-fungsi bangunan yang ada dalam tata letak tersebut mengacu jumlah sub wilayah Budaya Jatim, yakni ada tujuh wilayah Sub budaya.

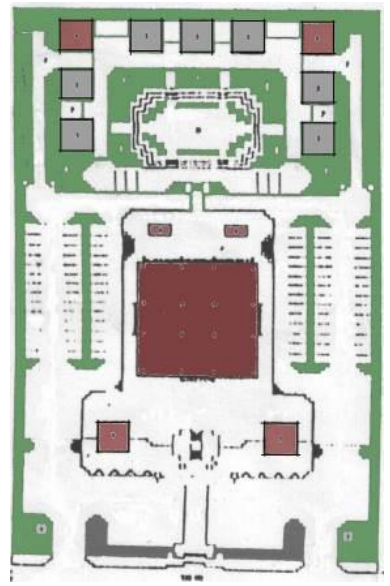

Gambar 24. Tata Ruang Kompleks Taman Krida Budaya Jatim Berpola Mengadopsi Tata Ruang Rumah Tradisional Jawa

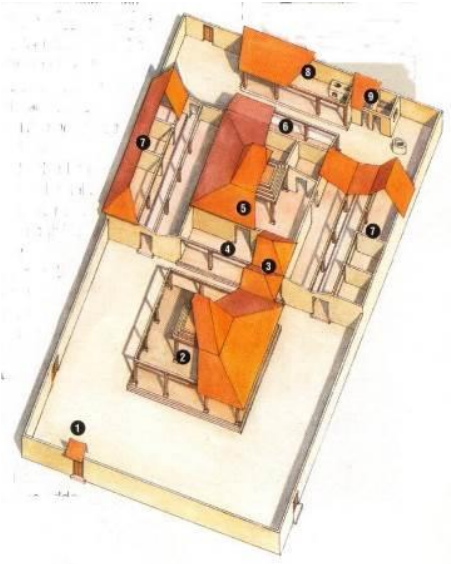

Gambar 25. Tata Ruang Rumah Tradisional Jawa sebagai Grand Design Penataan Ruang Taman Krida Budaya Jatim

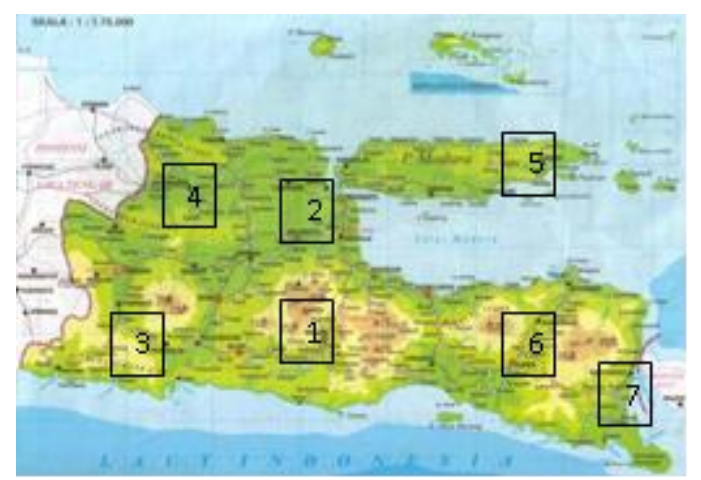

Gambar 26. Tujuh Wilayah Budaya Jawa Timur

\section{KESIMPULAN}

Taman Krida Budaya Jawa Timur dirancang dengan proses Popular Vernacular, yakni mengadopsi elemenelemen vernakular yang ada dan dianggap mewakili di Jawa Timur. Hal demikian, karena fungsi bangunan 
tersebut sebagai 'Rumah' (secara simbolik) bagi budaya Jawa Timur.

\section{REFERENSI}

Kasim S. 2012. Budaya Dermayu: Nilai-nilai Historis, Estetis dan Transendental. Poestakadjati, Yogyakarta.

Gotfried, Herbert \& Jennings Jan, 1988, American Vernacular Design, Iowa State University Press.

Geldern, R.H., 1982, Konsepsi Tentang Negara \& Kedudukan Raja di Asia Tenggara, Terjemahan, Deliar Noer, CV. Rajawali, Jakarta.

Rapoport, Amos, 1990, Development, Culture, Change and Supportive Design, Habitat Intl. Vo. 7, Printed in Great Britain.

Sumardjito, 1994, Fasad Bangunan Vernakular Kuno di Kotagede Yogyakarta, Laporan Penelitian, Universitas Gadjah Mada, Yogyakarta. 